currently provided by the learning center and the media support services provided by the instructional development unit.

The academic vice president reportedly is comfortable with the current structure and results, even though the merger was begun as an interim venture to solve an immediate problem. The longterm benefits in cost and simplification appear to be positive. The questions raised by the faculty have centered on how competent the library director would be to manage the computer technology, a discipline admittedly outside his previous experience. However, the incumbent's "facilitative" approach to those questions appears to have helped win support. The professors of computer courses reportedly were and remain the most wary about the consolidation, but the progress realized to date indicates that they too eventually will endorse the arrangement.

The staff at the college believes that for a merger to succeed there first must be a positive expectation of success, particularly among the staffs of the merged units. Of greater importance, however, are said to be the management and communication abilities of the individuals involved, and the willingness of the staffs to cooperate with one another.

\section{Issues Papers}

Members of the Task Force prepared a series of issues papers that provided background for the discussions at ALA Annual Conference in San Francisco. The group will attempt to complete a first draft of guidelines, with a view to completing them by January 1988.

\title{
ACRL actions, June 1987
}

\section{Highlights of the Annual Conference meetings of the ACRL Board of Directors.}

$\mathbf{T}$ he Board of Directors of the Association of College and Research Libraries met twice during the ALA Annual Conference in San Francisco: on June 27, 1987, and June 30, 1987.

\section{Accreditation}

While confirming its commitment to the MLS as the terminal degree for professional librarians, the Board voted to support an AASL proposal that ALA join the National Council for Accreditation of Teacher Education (NCATE) and designate AASL the responsible participant in the NCATE accreditation process as it relates to school library media education programs not eligible for accreditation by ALA.

\section{Acid-free paper}

The Board approved the following policy on the use of acid-free paper developed by the Publications Committee: "that by 1990, ACRL will begin publishing all serial publications of the Division on acid-free paper, with the exception of ephemeral publications such as but not limited to section newsletters and handbooks." The Publications Committee will review cases in which an exception is being requested to this requirement.

\section{ALA Divisions}

The Board had an opportunity to pose questions about the proposed "Policies of the American Library Association in Relation to Its Divisions" to members of ALA's Committee on Program Evaluation and Support (COPES). ACRL members Carla Stoffle, Richard Olsen, aıd Patricia Schuman represented COPES.

The Board endorsed a report to the ALA Execu- 
tive Board from the Special Committee on ASCLA (another division of ALA) and voted to support its recommendations, which include the preparation by ALA management of a specific proposal that will enable ASCLA to continue operations within its budget for FY1988.

\section{Audiovisual services}

The Board approved revised "Guidelines for Audio-Visual Services in Academic Libraries." These will be published in the October 1987 issue of $C \triangleleft R L$ News. The guidelines have been submitted to the ALA Standards Committee for approval.

\section{Awards}

The Board approved a proposal for the establishment of an annual Hugh Atkinson Memorial Award, named in honor of the late director of the University of Illinois Libraries. The award will be made to an academic librarian in mid-career for one or more of the following purposes: a) to recognize outstanding past accomplishments related to library automation which contributed in a significant way to the improvement of library services or to library development or research; b) to support a designated library automation project or research project related to library automation; c) to support advanced education in librarianship or information science. The Atkinson Awards Committee will be comprised of one member each from the divisions of ACRL, LAMA, and LITA. The proposal for the award has been submitted to the ALA Awards Committee for approval.

The Board approved the appointment of a task force to consider issues related to awards given within ACRL, for the purpose of recommending a comprehensive awards policy and a future "awards agenda" for ACRL.

\section{Budget}

The Board approved the 1988 ACRL budget with revenues of $\$ 753,252$ and expenses of $\$ 750,020$.

The Board approved a Budget and Finance Committee proposal that ACRL funds will be used to purchase capital items (e.g., office furniture and equipment) only when such items are to be housed in ACRL offices.

\section{Continuing education}

The Board approved the guidelines developed by the Professional Education Committee for ACRL Continuing Education Scholarships. ACRL plans to offer two free-tuition scholarships for ACRL professional development activities each year. Further details will be announced in $C \triangleleft R L$ News.

\section{Discussion groups}

The Board dissolved the Women's Studies Dis- cussion Group because it had been replaced by the Women's Studies Section.

The Board also approved petitions for the creation of two new discussion groups: Home Economics/Human Ecology Librarians; and Australian Studies.

\section{EBSS Bylaws}

The Board approved a revision to the EBSS Bylaws that adds the EBSS newsletter editor as a member of the section's Executive Committee.

\section{Extended campus library service}

The Board accepted the Planning Committee's recommendation to establish a new task force to review the Guidelines for Extended Campus Library Services. The review is scheduled for completion by the 1988 Annual Conference in New Orleans.

\section{Faculty/Librarian Workshops}

The Board approved ACRL's participation in planning for one or more faculty/librarian workshops, jointly with the American Association of University Professors. The purpose of the workshop would be to allow librarians and faculty members to cooperate in the improvement of the quality of higher education. An ad hoc committee will be appointed to carry out the planning and the project.

\section{Federal Acquisition Regulation}

The Board endorsed a resolution, sponsored by the GODORT Legislation Committee, relating to the Federal Acquisition Regulation (published in the March 20, 1987, Federal Register). It urges the Department of Defense, the General Services Administration, and NASA to rescind Subpart 8.8 that will allow certain executive agencies to bypass the printing procedures required by U.S. law, thereby reducing the authority of the Joint Congressional Committee on Printing over government printing and diminishing the amount of information available to the public through the Government Printing Office's Depository Library and sales programs. The resolution states that the regulation "will result in reduced access and higher fees for government information vital to the economic and social well being of the nation," and that it was implemented without any provision for public comment.

\section{Foreign nationals}

The Board endorsed a revised version of the ALA "Policy on Abridgement of the Rights of Freedom of Expression of Foreign Nationals" by the ALA International Relations Committee.

\section{Freedom to Read Foundation}

The Board voted to join the Foundation with a membership contribution of $\$ 300$. 


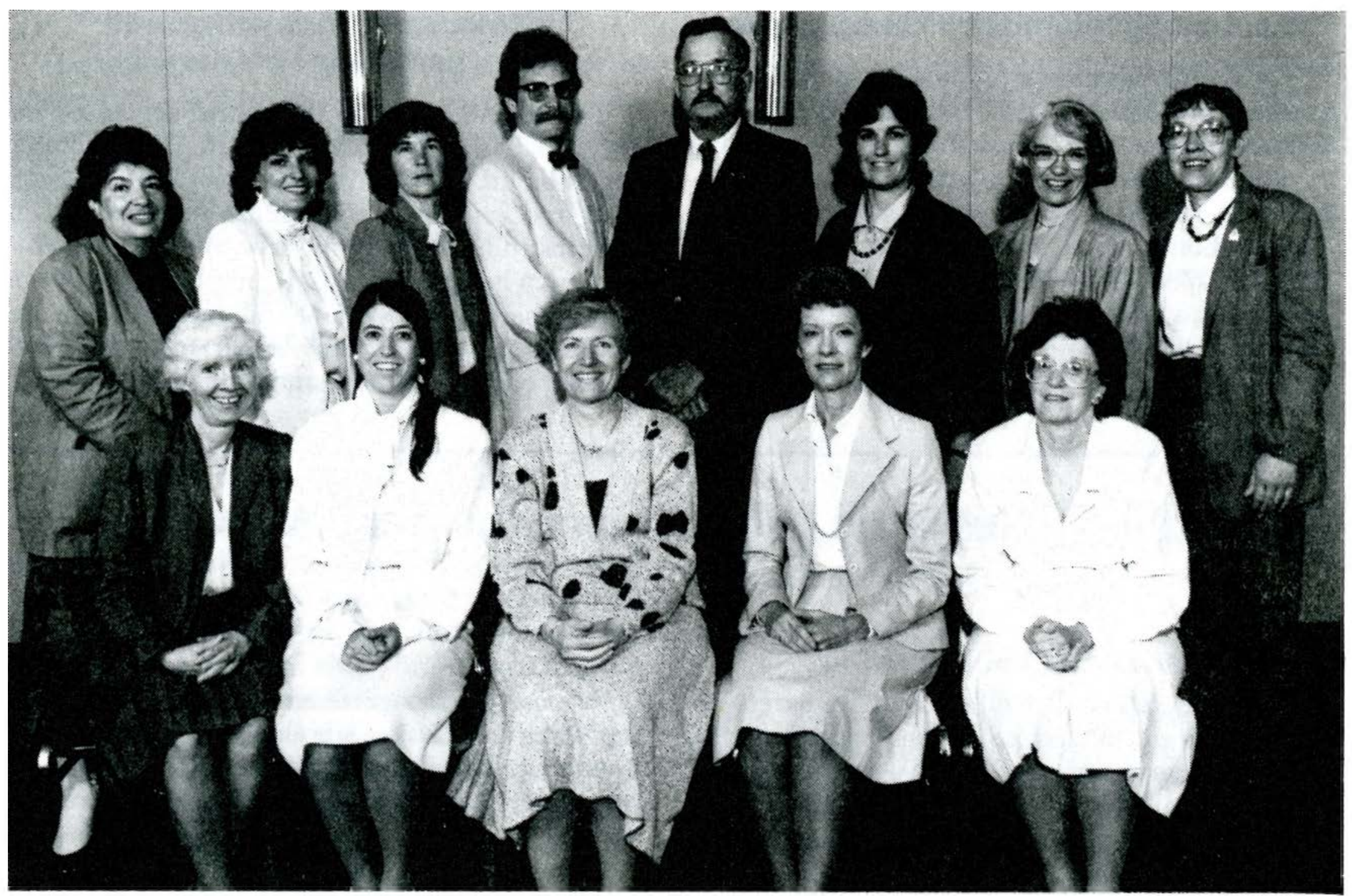

ACRL Board, 1986-87. Back row: Rochelle Sager, Anne Beaubien, Elizabeth Salzer, Lee Hisle, Bob Carmack, Mary Sue Ferrell, Patricia Wand, Alexandra Mason. Front row: JoAn Segal, Sharon Hogan, Hannelore Rader, Joanne Euster, Anne Commerton. Not present: Thomas Kirk, Edward Jennerich, Melvin George.

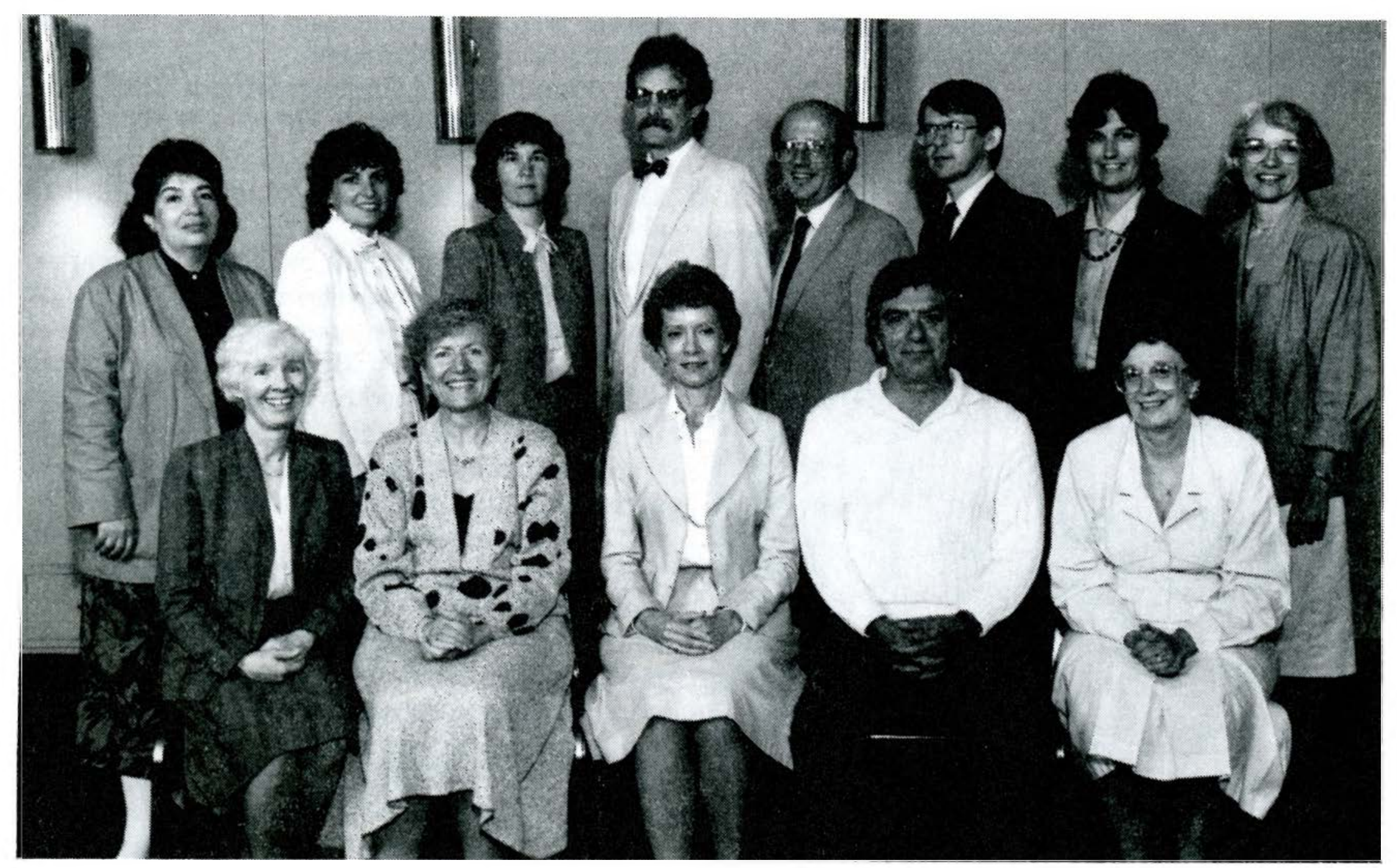

ACRL Board, 1987-88. Back row: Rochelle Sager, Anne Beaubien, Elizabeth Salzer, Lee Hisle, Peter Malanchuk, Larry Hardesty, Mary Sue Ferrell, Patricia Wand. Front row: JoAn Segal, Hannelore Rader, Joanne Euster, Joseph Boissé, Anne Commerton. Not present: Thomas Kirk, Edward Jennerich, Melvin George. 


\section{Fundraising Information Clearinghouse}

The Board endorsed a proposal prepared by the LAMA Fund-Raising and Financial Development Section and the ACRL Task Force on Fundraising to establish a Fundraising Information Clearinghouse in the ALA Headquarters Library. The Clearinghouse would provide books, periodicals, samples, specialized bibliographies, and a database of consultants and projects. The proposal will be submitted for ALA Executive Board approval and then to potential funders.

\section{Historically black college and university libraries}

The Board approved the charge for an ad hoc Historically Black College and University Library Planning Project Committee. The Committee will plan and conduct a colloquium for librarians in such institutions that will serve to elicit ideas concerning what projects ACRL might undertake on their behalf and to evaluate the internship project for black librarians that ACRL sponsored with support of the Mellon Foundation in 1975-1978.

\section{Academic or Research Librarian of the Year Award}

The Association of College and Research Libraries invites nominations for the Academic or Research Librarian of the Year Award, presented jointly by ACRL and the Baker \& Taylor Company. Anyone wishing to submit nominations should contact the ACRL Office, $50 \mathrm{E}$. Huron Street, Chicago, IL 60611-2795.

Recipients of the award since its inception in 1978 have been Keyes D. Metcalf and Robert B. Downs (1978); Henriette D. Avram and Frederick G. Kilgour (1979); Evan I. Farber (1980); Beverly P. Lynch (1981); William Budington (1982); Richard M. Dougherty (1983); Richard Johnson (1984); Jessie Carney Smith (1985); Margaret Beckman (1986); and Duane Webster (1987).

The Awards Committee selects persons to receive the award in accordance with the following guidelines:

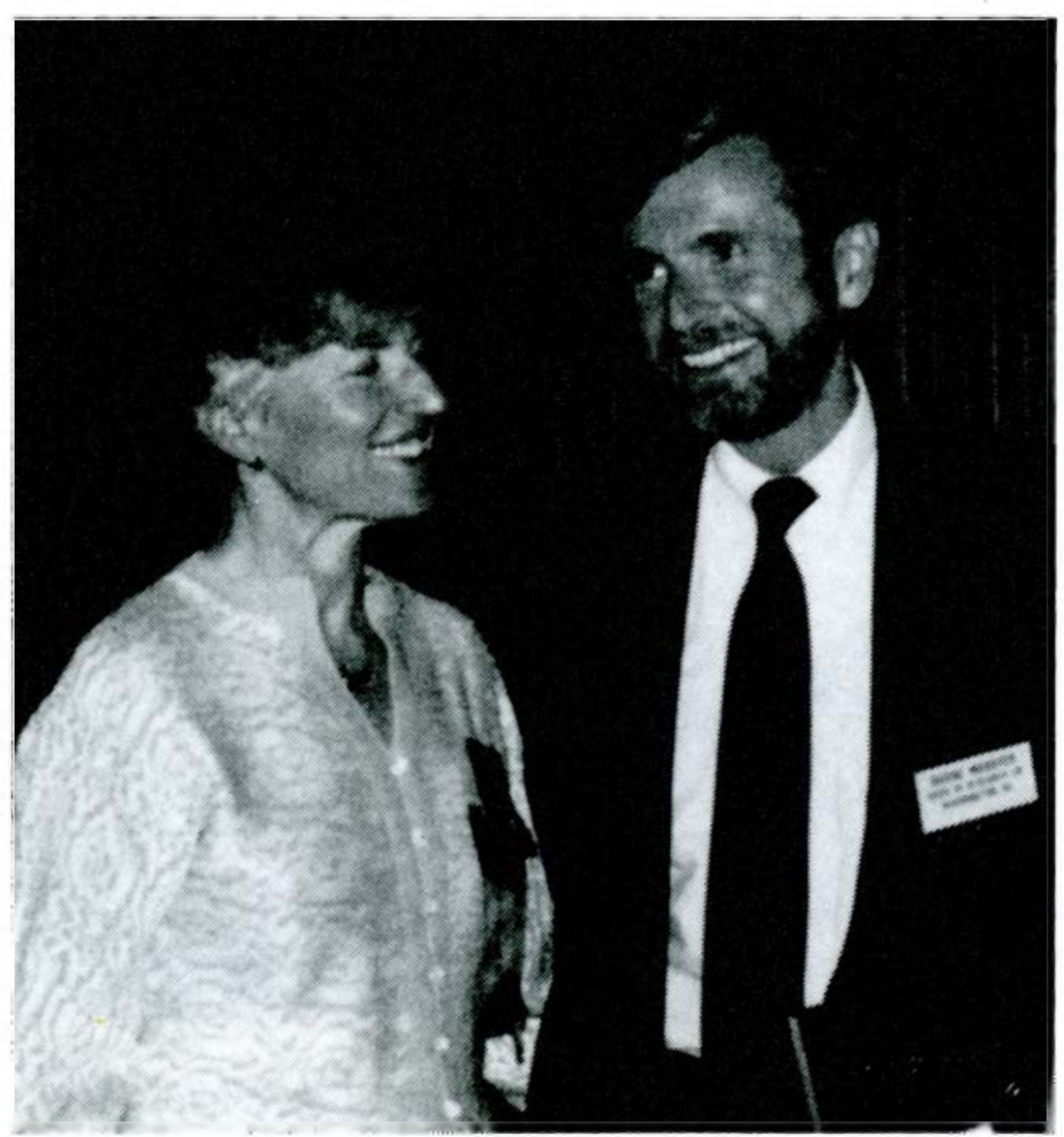

Hannelore Rader with Duane Webster at the award cermony.
Purpose: To recognize an individual member of the library profession who has made an outstanding national or international contribution to academic or research librarianship and library development.

Criteria: Individuals nominated should have demonstrated achievements in such areas as:

1. Service to the organized profession through ACRL and related organizations.

2. Significant and influential research on academic or research library service.

3. Publication of a body of scholarly and/or theoretical writing contributing to academic or research library development.

4. Planning and implementing a library program of such exemplary quality that it has served as a model for others.

5 . Nominee does not have to meet all of the above criteria.

Rules: The award shall be made each year at a time and place to be determined by the ACRL Board of Directors. Announcement of the award shall be made by the ACRL President at a time and place to be determined by the Board of Directors. If, in the opinion of the Award Committee, no worthy candidate is nominated in a given year, the award will not be presented that year.

Nominations: Nominations for the award must be made on forms available from the ACRL Office and must be postmarked no later than December 1, 1987. Eight copies of the nominations must be submitted and should be accompanied by a statement of supporting reasons and a copy of the nominee's resume. Please do not solicit supporting letters seconding your nomination. Such letters will not be considered in the Award Committee's decision.

Nature of the award: The Academic or Research Librarian of the Year Award shall consist of $\$ 3,000$ and an appropriate citation.

For more information please contact Mary Ellen K. Davis, ACRL/ALA, 50 E. Huron Street, Chicago, IL 60611-2795; (312) 944-6780. 


\section{Libraries and academic excellence}

The Board referred the action agenda from the symposium, "Libraries and the Search for Academic Excellence," co-sponsored by Columbia's School of Library Service and the University of Colorado, to the ACRL Vice-President/PresidentElect for his consideration as activities of ACRL.

\section{Libraries and Computer Centers}

The Board received the progress report of the Task Force on Libraries and Computer Centers. The report appears on pp. 442-47.

\section{Library Faculty Workshop}

The Board approved the cooperation of ACRL in an Association of Research Libraries project, "Institute on Research Libraries." The project will place 12 library school faculty members into academic libraries for field visits; bring them together later in a workshop to discuss their observations with each other and with librarians; and highlight the key issues in academic librarianship through discussion and publication of written work growing out of the Institute.

\section{Membership}

The Board approved the recommendation of the Planning Committee that the Membership Committee conduct an analysis of membership needs on a continuing basis.

\section{Performance measures}

The Board approved an RFP to write a manual of output measures for academic libraries.

\section{Planning workshop for small college libraries}

The Board approved in principle a proposal to license ARL/OMS planning materials for small and medium-sized libraries. In a workshop setting, teams of key staff members will use the ARL materials, already tested for effectiveness, allowing the teams to expand their understandings through contact with teams from other institutions and through work on a hypothetical case study. The ACRL staff will proceed with the development of a proposal and submit it to potential funders.

\section{Publications in Librarianship}

The Board endorsed a proposed volume on the research literature of academic librarianship; agreed to furnish a subvention of $\$ 1,500$; agreed to forego ACRL's share of $40 \%$ of the first $\$ 1,500$ of royalty (advanced by ALA); and agreed that ACRL would receive its $40 \%$ share of any royalties beyond those advanced by ALA.

The Board approved the appointment of Jonathan A. Lindsey as the editor of the ACRL Publications in Librarianship series for the five-year period beginning in July 1988.
12 Lunar Drive/Drawer AB Woodbridge, CT 06525 Toll-free: 1-800-REACH-RP TWX: 710-465-6345 FAX: 203-397-3893

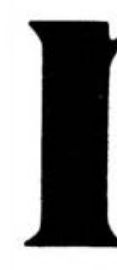

\section{Two hundred historic years of The World's news in microform.}

Over 200 years of factual reporting ... dozens of acclaimed international newspapers like The Times, The Washington Post, Le Monde, Der Spiegel, Asahi Shimbun, The Age, Financial Times, Jewish Chronicle ... all of them available on microfilm from Research Publications.

This is probably the most inexhaustible, highquality collection of international newspapers ever preserved in microform - perfect for scholars, researchers, and the general public.

For further information, or to order current subscriptions and backfiles, call Research Publications today at 1-800-REACH-RP (1-800-732-2477). From Connecticut, Alaska and Canada, call collect 203-397- 2600. 


\section{Rare Books \& Manuscripts Librarianship}

The Board voted to incorporate the journal, Rare Books and Manuscripts Librarianship, as part of its ongoing publications program.

\section{Research}

The Board approved a proposal to hold a research workshop in FY1988 that will encourage more research in librarianship and stimulate activity in preparation for the ACRL National Conference in Cincinnati. An ad hoc committee will be appointed to plan for the workshop.

The Board approved the recommendation of the Planning Committee to rewrite the charge of the Research Committee as follows: "To explore, develop and promote a research agenda which focuses on the current research needs of academic/research libraries and of the association; to develop programs and other activities which will assist in the accomplishment of the needed research; to develop activities and programs to encourage improvement in research skills among academic/research librarians."

\section{Section directories}

The Board directed the ACRL staff to investigate further the possibility of producing one or more directories of section membership using the new ALA membership system.

\section{Selection of general collection materials for transfer to special collections}

The Board approved the "Guidelines on the Selection of General Collection Materials for Transfer to Special Collections," developed by an ad hoc committee of RBMS. The guidelines appear in this issue on pp. 471-74, and have been submitted to the ALA Standards Committee for final review.

\section{Statistics}

The Board agreed to commit ACRL, in principle, to the collection of academic library statistics. The Board gave its approval for the Academic Library Statistics Committee to pursue alternative sources of funding to collect statistics for the $1987 / 88$ academic year for all academic libraries in the United States with budgets over $\$ 100,000$, using questionnaires developed in last year's project.

\section{Strategic planning}

The Board approved the Annual Operating Plan for FY1988 developed by the Planning Committee. A copy of the Operating Plan may be requested from the ACRL Office.

\section{Suite}

The Board voted to continue the practice of having an ACRL suite at ALA Midwinter Meetings

\section{DIRECTORY OF SERVICES FOR REFUGEES AND IMMIGRANTS}

Directory of nearly 900 ethnic, religious and community organizations; voluntary and governmental agencies; and legal services corporations that provide social, economic and cultural services to refugees, immigrants and the undocumented. Arranged by state. Fourteen indexes.

$$
\text { Sept. } 1987 \text { 375p. } 0-938737-12-0 \quad \$ 27.95
$$

\section{GUIDE TO SMITHSONIAN SERIAL PUBLICATIONS}

Annotated listing, with author/title/subject indexes for all monographs in the following fourteen Smithsonian serials published between 1964 and 1986:

Contributions to Anthropology; Botany; Paleobiology; Earth Sciences; Marine Sciences; Zoology

Publications in Salvage Archeology

RIIES Bibliographic Studies; Occasional Papers; Research Notes

Annals of Flight; Folklife Studies

Studies in Air and Space; History and Technology

$$
\text { Nov. } 1987 \quad 302 \text { p. } \quad 0-938737-13-9 \quad \$ 27.95
$$

Both books were prepared by Alan Edward Schorr, former University Librarian and Dean at the California State University, Fullerton and Library Director at the University of Alaska, Juneau. He is the author of 9 books and over 200 articles, essays and reviews.

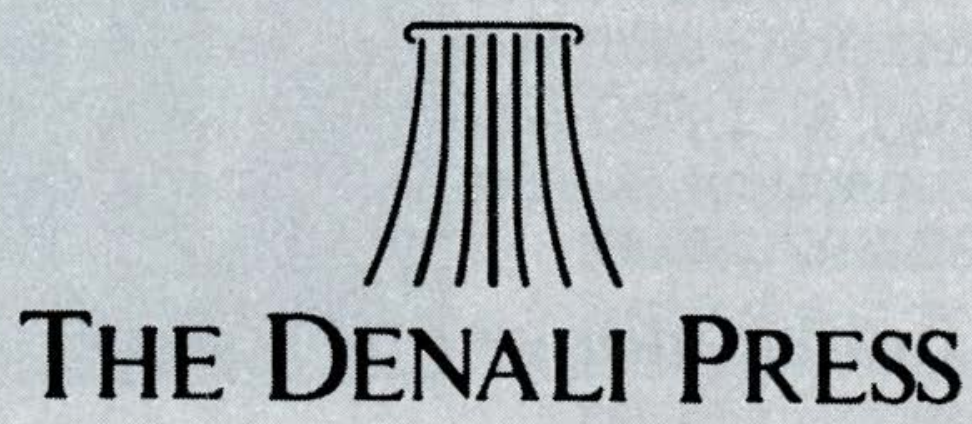

Post Office Box 021535 Juneau, Alaska USA 99802-1535 Telephone (907) 586-6014 
and Annual Conferences. The practice will be reviewed again in 1990 .

\section{Surplus funds}

The Board approved the recommendation of the Planning Committee to establish a new standing Committee to Allocate Surplus Funds.

\section{Surveys}

The Board approved a policy on ACRL surveys whereby any questionnaires to be sent beyond the membership of a specific ACRL group or committee are to be submitted to the ACRL Executive Di- rector for review. The review is intended to prevent duplication of effort among units, ensure conformity to ACRL policies, and ensure that questionnaires meet a basic level of quality and are appropriate to the proposed investigation.

\section{Undergraduate library mission}

The Board approved the "The Mission of a University Undergraduate Library (Model Statement)" developed by the Undergraduate Librarians Discussion Group and the ULS Steering Committee. This document will appear in the October issue of C\&RL News, and has been sent to the ALA Standards Committee for final review.

\section{Nijhoff International West European Specialist Study Grant}

Applications are being solicited for the ACRL Western European Specialist Section's Martinus Nijhoff International West European Specialist Study Grant.

The purpose of the new grant is to provide support for an American Library Association member to visit the Netherlands and then to spend ten consecutive working days visiting two other West European countries to study some aspect of West European librarianship or bibliography.

The study grant is funded by Martinus Nijhoff, Booksellers and Subscription Agents, The Hague, and is administered by the Western European Specialists Section of ACRL. The grant is awarded annually and covers air travel to and from Europe, surface travel in Europe, lodging and board.

Six copies of the application should be submitted and should contain a detailed description of the proposed project and an explanation of the value of the project to the library community.

The primary criterion for awarding the grant will be the significance and utility of the proposed project as a contribution to the study of the acquisition, organization, or use of library materials from or relating to Western Europe.

The jury responsible for awarding the grant will consist of three members of the WESS; two members of Nijhoff International will serve as consultants to the jury.

A report of no less than 4,000 words on the research resulting from the study trip is to be submitted to the jury no later than six months after the final day of the trip. It is assumed that in most cases this report will be suitable for publication; if so, ACRL will be given first right of refusal.

If the grant recipient wishes to remain in Europe for longer than the ten days covered by the grant, this may be done at the recipient's own expense. The deadline for applications for the 1988 grant will be December 1, 1987.

The winner of the grant will be announced at the WESS membership meeting at the 1988 ALA Annual Conference. Applications should be sent to Mary Ellen K. Davis, ACRL/ALA, 50 E. Huron Street, Chicago, IL 60611-2795; (312) 9446780 .

\section{Internships for West German librarians}

The library school of the Free University of Berlin is most interested in finding salaried internship/practicuum possibilities for the graduates of their library programs in any type of U.S. library.

These students specialize in either public library work or academic library work and do receive good computer training. For more details contact: Professor Robert Funk, Free University Berlin, Institute for Library Science, Hohenzollerndamm 56, 1000 Berlin 33, West Germany. You may also contact Hannelore B. Rader, Director of Libraries, Cleveland State University Libraries, 1860 E. 22nd St., Cleveland, $\mathrm{OH} 44115$. 


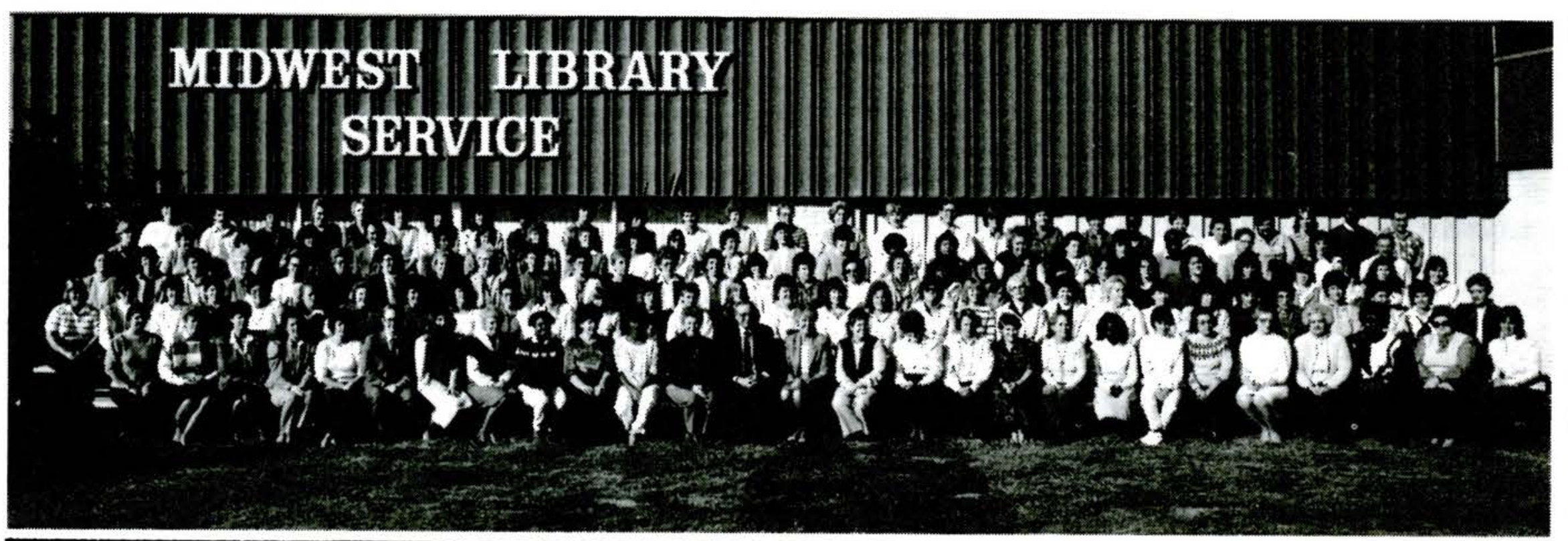

\section{MLS-160 People, 27 Years of Service to Libraries}

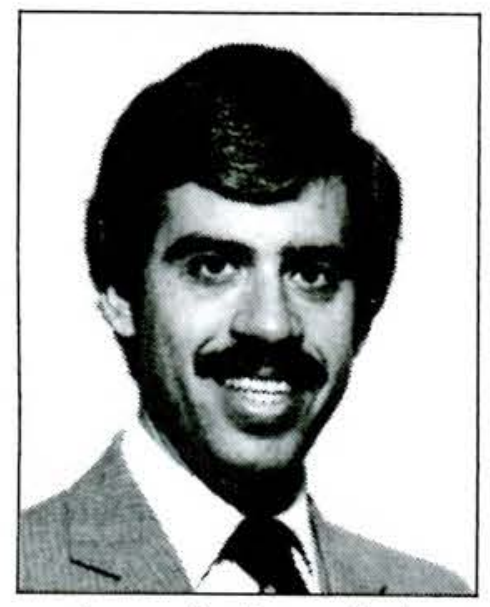

Jay Askuvich General Sales Manager

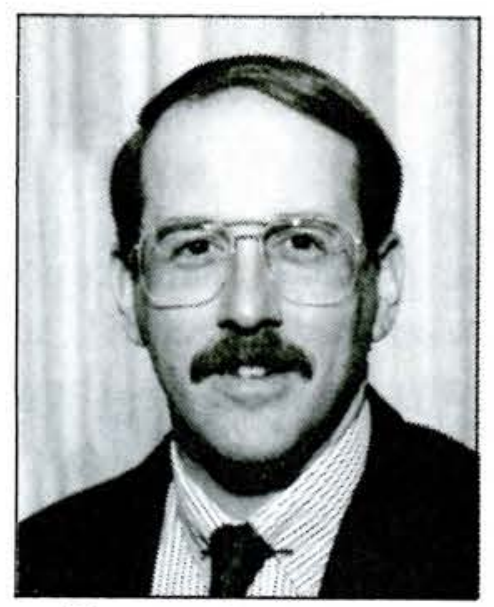

Scott Schmidt Midwest

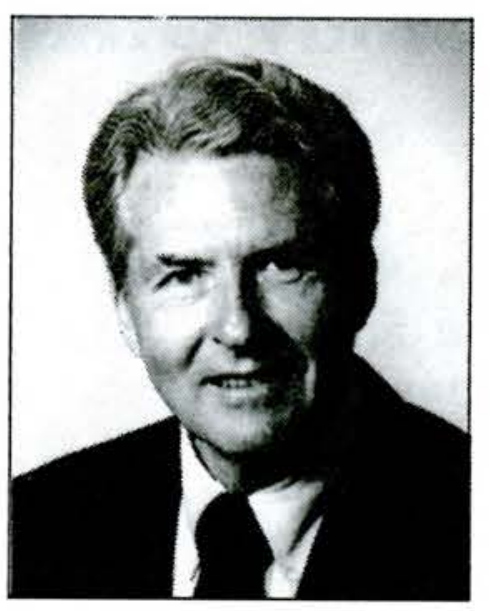

Carl Dorr Southeast

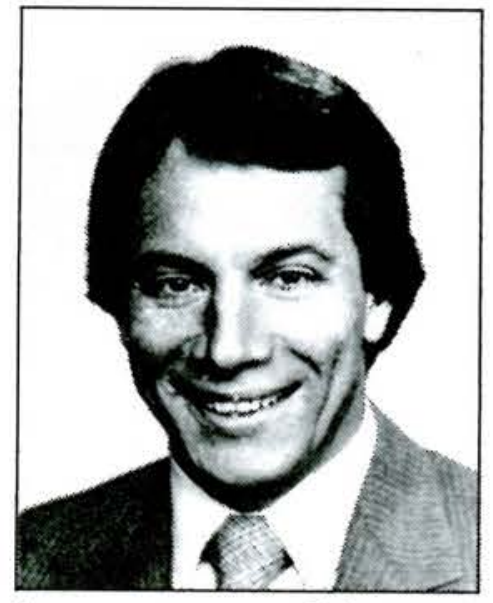

Lawrence Nagel West

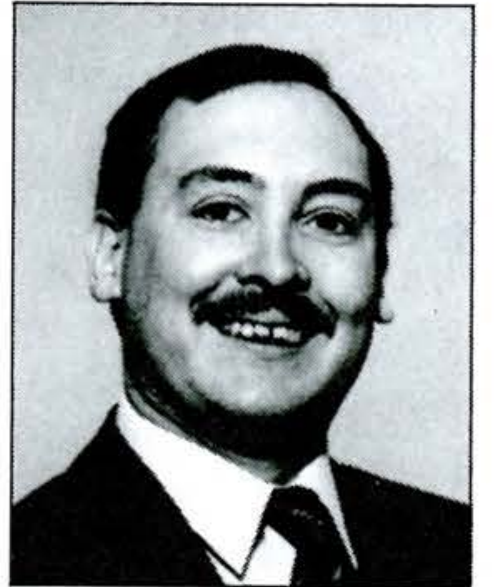

Forrest Link Northeast

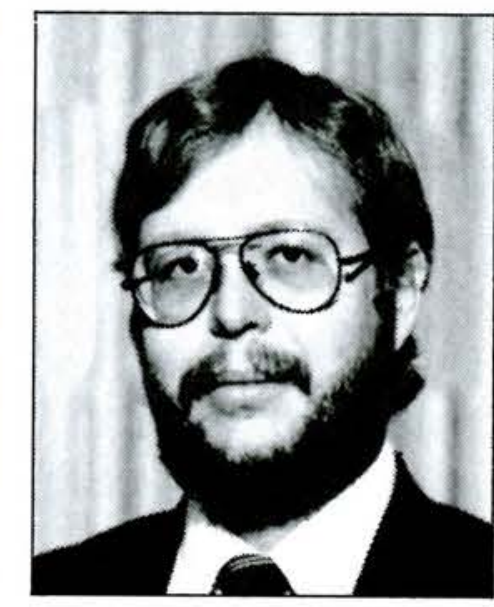

Kim Anderson Mountain Plains

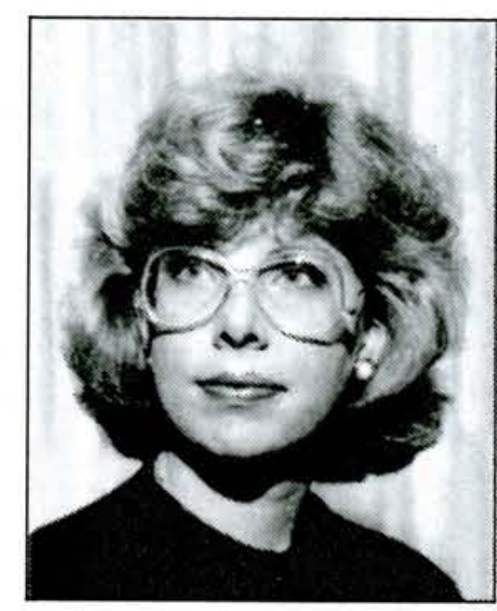

Lorraine Best Canada

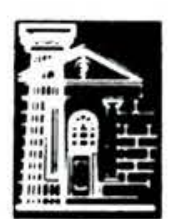

\section{Midwest Library Service}

11443 St. Charles Rock Road Bridgeton, MO 63044, USA

Call toll-free 1-800-325-8833

Missouri librarians call toll-free 1-800-392-5024

Canadian librarians call toll-free 1-800-527-1659 